Reprod. Nutr. Dévelop., 1988, 28 (6 B), 1707-1730

\title{
Ovine chorionic somatomammotropin and foetal growth
}

\author{
Nicole CHÊNE, J. MARTAL, J. CHARRIER ( $\left.{ }^{*}\right)$
}

I.N.R.A., Unité d'Endocrinologie de l'Embryon, Station de Physiologie animale, 78350 Jouy-en-Josas, France.

${ }^{*}$ ) I.N.R.A.-E.N.S.A., Station de Physiologie animale,

Place Viala, 34060 Montpellier cedex, France.

Summary. Ovine chorionic somatomammotropin (oCS) enhances the weight and bone growth of hypophysectomized rats. It acts as a bifunctional hormone, since it binds both to lactogenic and somatotropic receptors. Ovine foetus weight gain is closely related to oCS and oGH serum levels. oCS is able to stimulate somatomedins by foetal liver. Moreover, oCS specific receptors are present in some foetal tissues. So, all these facts involve oCS in foetal growth, whereas pituitary growth hormone intervenes in postnatal growth. A study of structure function relationships between growth hormones and placental hormones is exposed in order to localize somatotropic sites.

\section{Introduction.}

It has been well established that foetal pituitary contributes only partially to embryonic development since anencephalic foetuses from rabbits (Jost, 1947), humans (Brewer, 1957 ; Erez and King, 1968) and cattle (Cho and Leipold, 1978) develop almost normally. In the sheep, only a slightly delayed growth is observed after foetal hypophysectomy (Liggins and Kennedy, 1968). The weight of ruminant foetuses increases up to day 50 of gestation, i.e. before the appearance of foetal pituitary which releases growth hormone $(\mathrm{GH})$, as demonstrated by Stokes and Boda (1968) and Bassett and Thorburn (1970). In 1957 Contopoulos and Simpson provoked an increase in the size of thymus, the width of the epiphyseal plate cartilage of the tibia and the body weight of hypophysectomized rats after injections of variable doses of plasma from pregnant rats.

All these results suggest the existence of somatotropic secretions of extrahypophyseal origin. The involvement of placenta (suspected up to now) was evidenced when the binding of ovine placental lactogen hormone to somatotropic receptors was demonstrated as well as its capacity to stimulate bone growth of hypophysectomized rats (Chan et al., 1976; Martal and Djiane, 1976). The name of ovine chorionic somatomammotropin (oCS) results from its mammotrophic and growth promoting properties. Placental lactogen hormones are all endowed with a lactogenic activity but some seem to be deprived of growth activity, e.g., human ( $\mathrm{hPL}$ ), mouse (mPL) and rat ( $\mathrm{rPL}$ ) placental lactogens 
which are not able to bind to somatotropic receptors. Some species are even deprived of this hormone such as cats, dogs, rabbits, pigs and horses (Martal, 1981).

Thus, placental lactogen (PL) or chorionic somatomammotropin (CS), is not alone involved in foetal growth. Other placental hormones such as human placental growth hormone (hPGH), evidenced by Hennen et al. (1985), and proliferin (Linzer and Nathans, 1984) are endowed with a growth activity. A human growth factor of placental origin has been recently evidenced by Sen-Majumdar et al. (1986).

The purpose of the present paper was to demonstrate the action of oCS on overall growth and, in particular, on foetal growth. Some mechanisms of action and the regulation of oCS will be mentioned. Moreover, a comparative study of the structure-function relationships between growth hormones and placental hormones deprived of this growth activity (hPL) could explain the existence of the molecular sites responsible for this somatotropic activity. Growth factors involved in foetal growth will be reviewed.

\section{oCS : isolation, characterization, properties.}

Ovine chorionic somatomammotropin was the first animal placental lactogen to be purified. Several teams have isolated and characterized it (Handwerger et al., 1974; Hurley et al., 1975 ; Martal and Djiane, 1975; Chan et al., 1976). The isolation and purification of this hormone were facilitated by the determination of the growth activity using the radioreceptor assay developed by Tsushima and Friesen (1973). oCS is a polypeptide with an apparent molecular weight ranging between 22,000 and 23,000 and with an amino acid composition close to that of oGH and oPRL (ovine prolactin) (Hurley et al., 1977b). Chan et al. (1986) have identified two forms, oPL-1 and oPL-2, with different relative mobilities after high performance liquid chromatography (HPLC) on anionic exchange column. These authors confirmed the presence of 2 tryptophan residues and 6 cysteine residues, thus relating this molecule to both the growth hormone and the prolactin families. Two forms of oPL have also been observed in our laboratory on cation-exchange (Chêne, 1987 ; Sade, 1987). The isoelectric point ranges between $\mathrm{pH} 6.7$ and 8.4 according to the authors. A phenylalanine residue characterizes the $\mathrm{COOH}$ terminal of oCS and oGH (Hurley et al., 1977b). The predominant $\mathrm{N}$-terminal amino acid seems to be represented by valine (Caridad and Wolfenstein-Todel, 1988). oCS does not exhibit any immunological cross-reaction with antibodies against oPRL, oGH, bGH, hGH (ovine, bovine, human growth hormones) and hPL (Martal and Djiane, 1975; Martal, 1978a, b; Reddy and Watkins, 1978). oCS displays a double function since it is capable of binding to somatotropic receptors of rabbit hepatocyte membranes and to mammary gland lactogenic receptors from rabbits, as demonstrated by Martal (1980) using an original technique of affinity chromatography. oCS secretion is located in the binucleated cells of foetal cotyledons as shown by immunofluorescence (Martal et al., 1977). The occurrence of oCS in the trophoblast is observed from day 16 of gestation (Martal and Djiane, 1977) parallel to that of binucleated cells (Boshier, 1969). 


\section{oCS and metabolisms.}

Few studies have been devoted to the metabolic activities of oCS compared to those of hPL. However, we wish to mention the works of Handwerger et al. :

- Carbohydrate metabolism: Those authors showed that injection of partially purified oCS into pregnant (or non-pregnant) ewes led, following a short insulinemia depression, to hyperinsulinemia associated to hypoglycemia $8 \mathrm{~h}$ after injection (Handwerger et al., 1976). This insulin stimulation confirms that observed in man after hPL injection (Beck and Daughaday, 1967 ; Grumbach et al., 1968) or after the addition of $b G H$ to pancreatic cells of rat (Martin and Gagliardino, 1967). oCS administration depresses the plasma glucose concentration by about $40 \%$ as well as plasma amino nitrogen levels.

- Lipid metabolism: Free fatty acid concentrations (FFA) decrease one hour after oCS injection into pregnant (or non-pregnant) ewes. This effect persists $6 \mathrm{~h}$ later (Handwerger et al., 1976). According to Brinsmead et al. (1980), oCS does not possess any lipolytic activity. By contrast, injections of growth hormone to normal or hypophysectomized ewes after prolonged fasting enhance the FFA levels in blood (Vézinhet et al., 1974). Despite these contradictory results, the fact that hGH, bGH and hPL have a lipolytic effect (Mac Millan, 1979) suggests a similar activity for oCS. Besides the fact that foetal fatty tissue represents only $2 \%$ of the body weight at birth (Rattray et al., 1974), indicates that oCS may play a minor part in foetal lipid metabolism.

Because of its anabolic and diabetogenic activities, oCS supplies the foetus with glucose, a main metabolite in ruminants (Alexander, 1966), and with amino acid via insulinic effect.

- Protein metabolism : It has been demonstrated that oCS is involved in the transport of amino acids (for instance $\alpha$-aminoisobutyric acid in rat diaphragm) whereas hPL or oGH are not (Freemark and Handwerger, 1982). The involvement of oCS in foetal metabolism of amino acids and proteins has been confirmed by Butler et al. (1978) and Hurley et al. (1980). oCS injection to rat foetuses stimulates liver ornithine decarboxylase activity. This enzyme catalyzes the conversion of ornithine to putrescine involved in the biosynthesis of polyamines, spermine and spermidine, steps in protein and amino acid synthesis. By contrast, ovine and rat prolactins and ovine and rat growth hormones stimulate this enzyme activity but only in newborn or 17-day old rats.

It has been shown that oCS also stimulates the protein synthesis of rabbit mammary gland in organotypic culture, inducing the synthesis of lactose and $\beta$-casein and enhancing $\beta$-casein m-RNA (Servely et al., 1983).

In vivo and in vitro in homologous system, oCS displays a mammogenic and lactogenic activity similar to that of antehypophyseal hormones (PRL $+\mathrm{GH}$ ) (Martal, 1980). The metabolic activities of oCS of maternal as well as from of foetal origin, suggest that this hormone acts as a foetal growth hormone.

\section{Growth properties of oCS.}

The growth activity of oCS has been studied using several tests in heterologous species. The weight gain of hypophysectomized Wistar rats has 


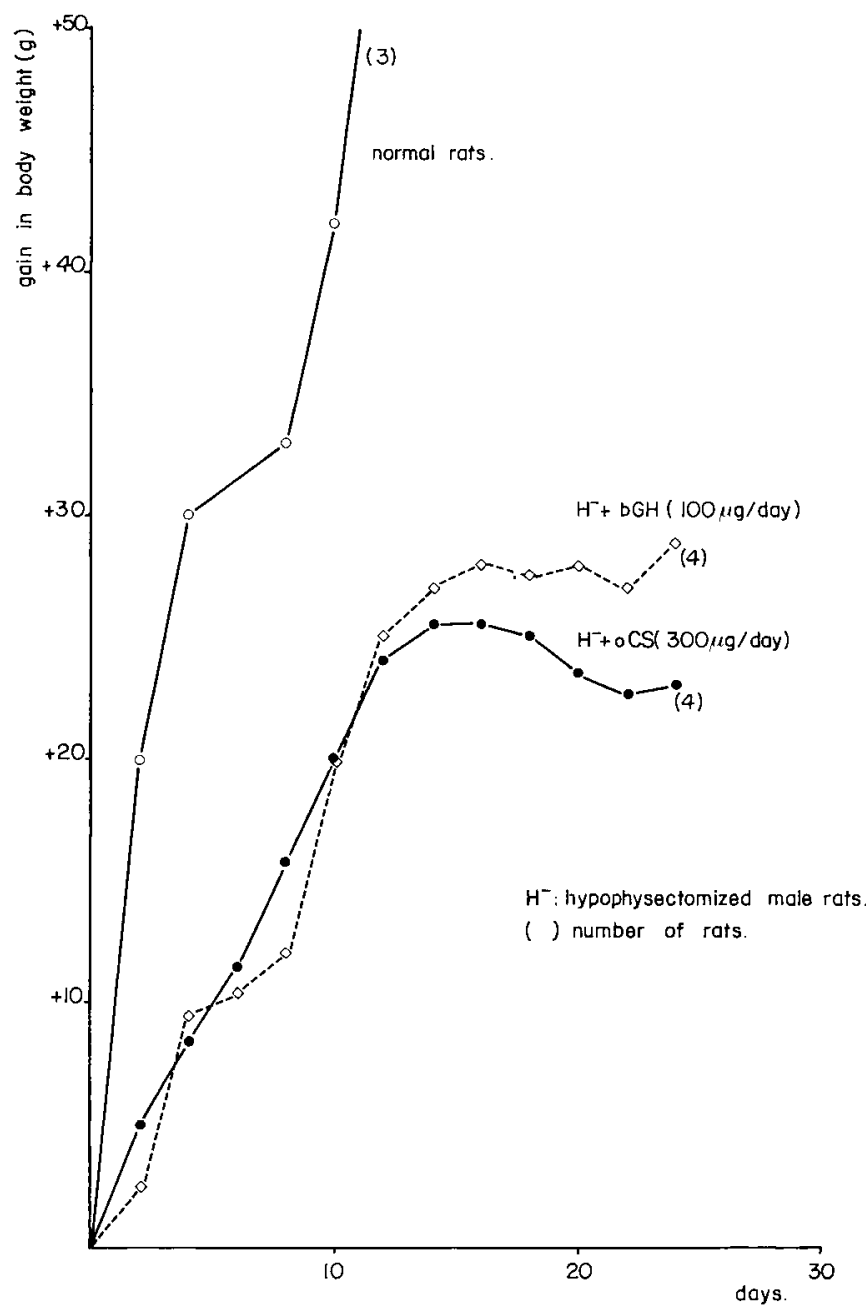

FIG. 1. - Weight gain of normaland hypophysectomized Wistar rats, weighing about 100 g, injected with $b G H$ or oCS for 3 weeks. Day 0 is the hypophysectomy day.

been achieved by oCS (prepared in our laboratory) injection (Martal, 1978, 1980) (Fig. 1, 2). It was similar to that observed after bGH (Pentex $1 \mathrm{UI} / \mathrm{mg}$ ) injection. In these conditions, a thickening of the epiphyseal cartilage plate of the tibia of hypophysectomized rats is observed (Martal and Djiane, 1977) (Fig. 3).

These in vivo experiments demonstrate the growth activity of oCS and suggest an effect on foetal growth.

\section{Foetal growth and oCs.}

Change in the foetal weight of Préalpes du Sud ewes is shown in figure 4. Although the hypophyseal growth hormone has not yet appeared (occurrence on 


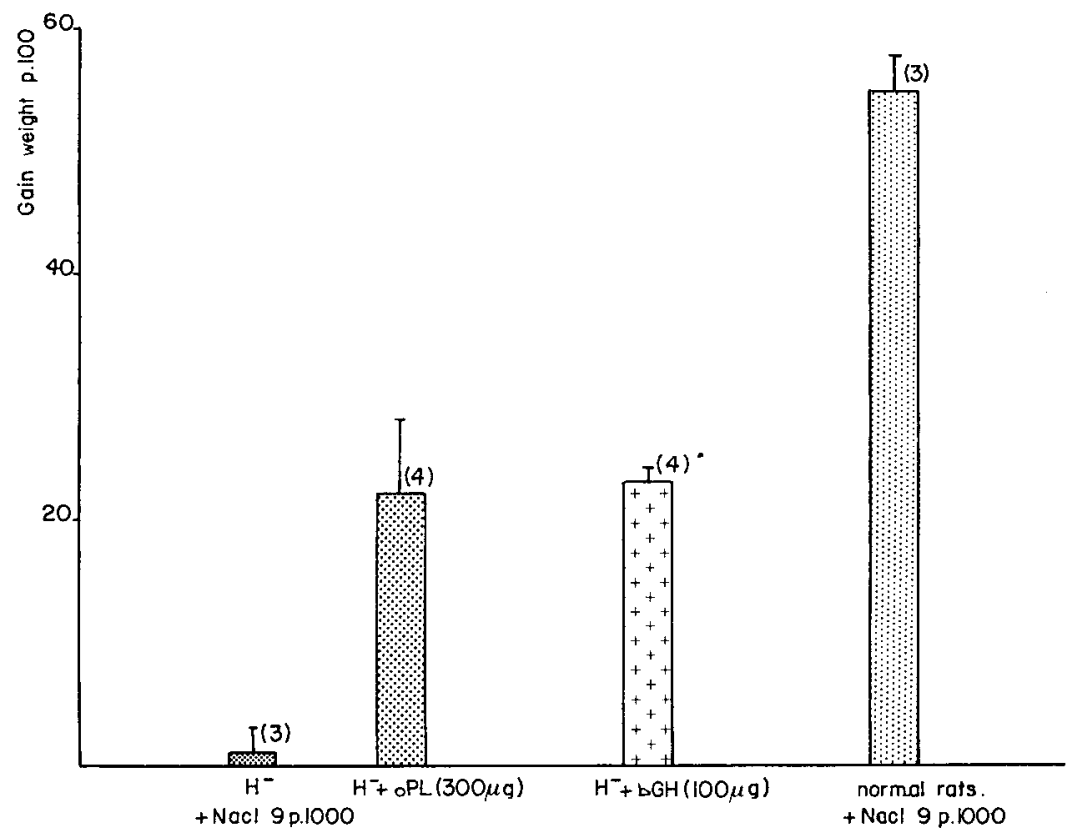

FIG. 2. - Weight gain of hypophysectomized rats injected with bGH and oCS for 3 weeks compared to that of normal or hypophysectomized animals.

day 50 of gestation) foetal weight gain and oCS production (from day 16 of pregnancy) go on and increase exponentially on day 20 to day 30 of gestation (Fig. 5). A close adjustment between total circulating growth activity and foetal weight gain is observed (Fig. 6). A linear relationship between foetal weight $P$ and the whole growth activity $\times(\mathrm{oCS}+\mathrm{oGH})$ can be established as follows (Fig. 7)

$$
\mathrm{P}(\mathrm{g})=172,5 \times(\mu \mathrm{g}) / \text { foetus }+57,2 .
$$

The total concentration of growth activity in foetal serum (oCS $+\mathrm{oGH}$ ) evaluated during gestation remains almost constant, ranging around $200 \mathrm{ng} / \mathrm{ml}$ from day 60 to day 140 (Fig. 8). By contrast, the relative concentration of both hormones changes considerably since on day 120 of pregnancy the foetal oCS concentration is almost twice that of oGH (Fig. 9). The serum oGH levels correspond to those indicated by Bassett et al. (1970).

\section{Regulation of oCS secretion.}

The effect of bromocriptine, a hypoprolactinemic drug, on pregnant ewes was studied relative to the levels of placental oCS and foetal and maternal serum oCS. Bromocriptine injection on day 70 of pregnancy induces a noticeable increase (4-6-fold) in placental oCS concentration relative to normal ewes. The 


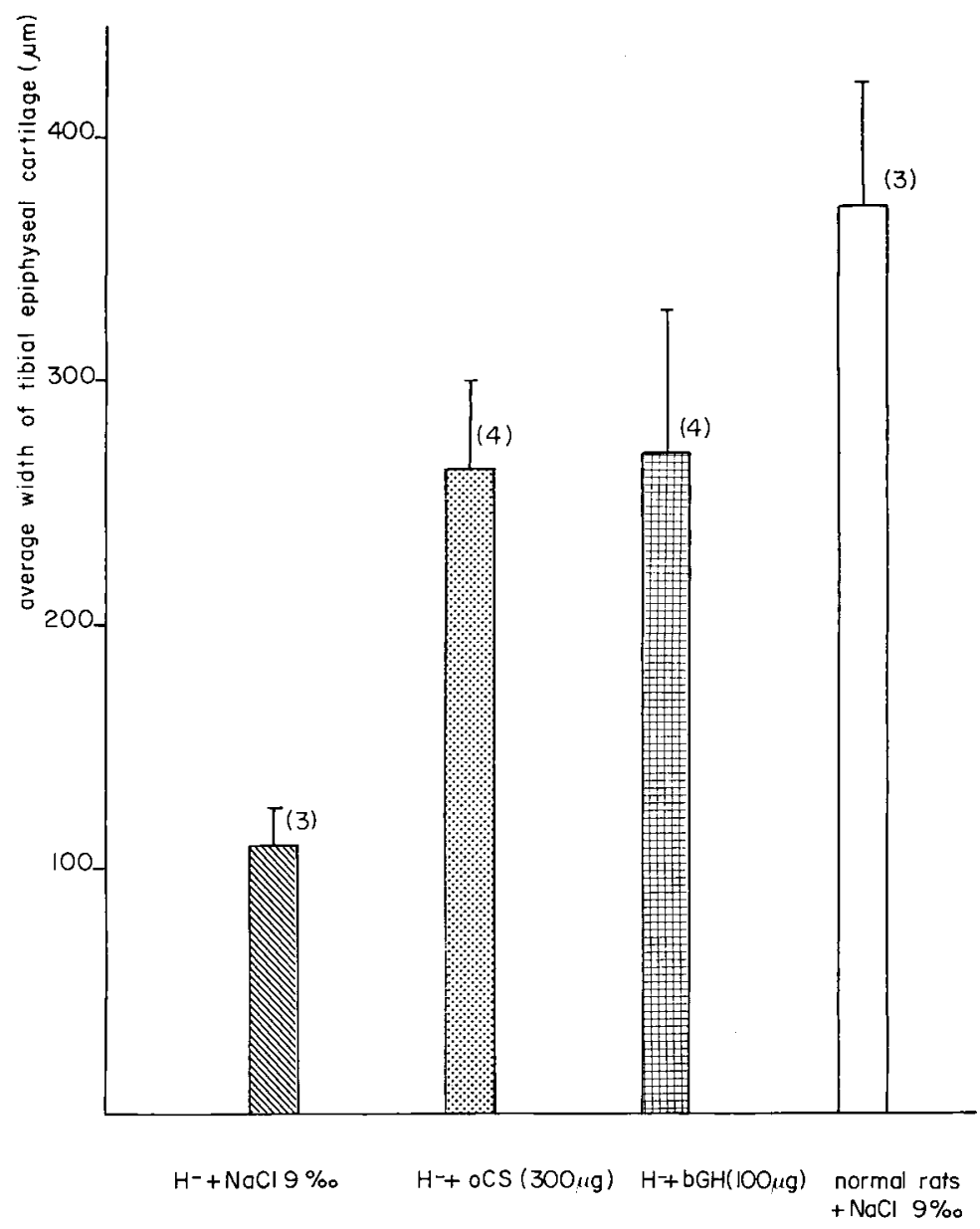

FIG. 3. - Mean thickness of epiphyseal cartilage plates of normal rats and hypophysectomized rats. treated by $b G H$ and oCS injection for 3 weeks.

placental oCS level falls between day 110 of gestation and lambing to reach that of normal ewes (Fig. 10). These results have not been explained yet. By contrast, no variation is observed in maternal or foetal oCS serum concentrations relative to control animals during bromocriptine treatment (Table 1). The latter does not affect either the cotyledon or foetal weight (Martal and Lacroix, 1978).

Ovine foetal hypophysectomy does not modify the maternal and foetal oCS plasma concentrations between day 115 and parturition (Taylor et al., 1983). It even inhibits the sharp drop of oCS a few days before parturition (Taylor et al., 1980). 


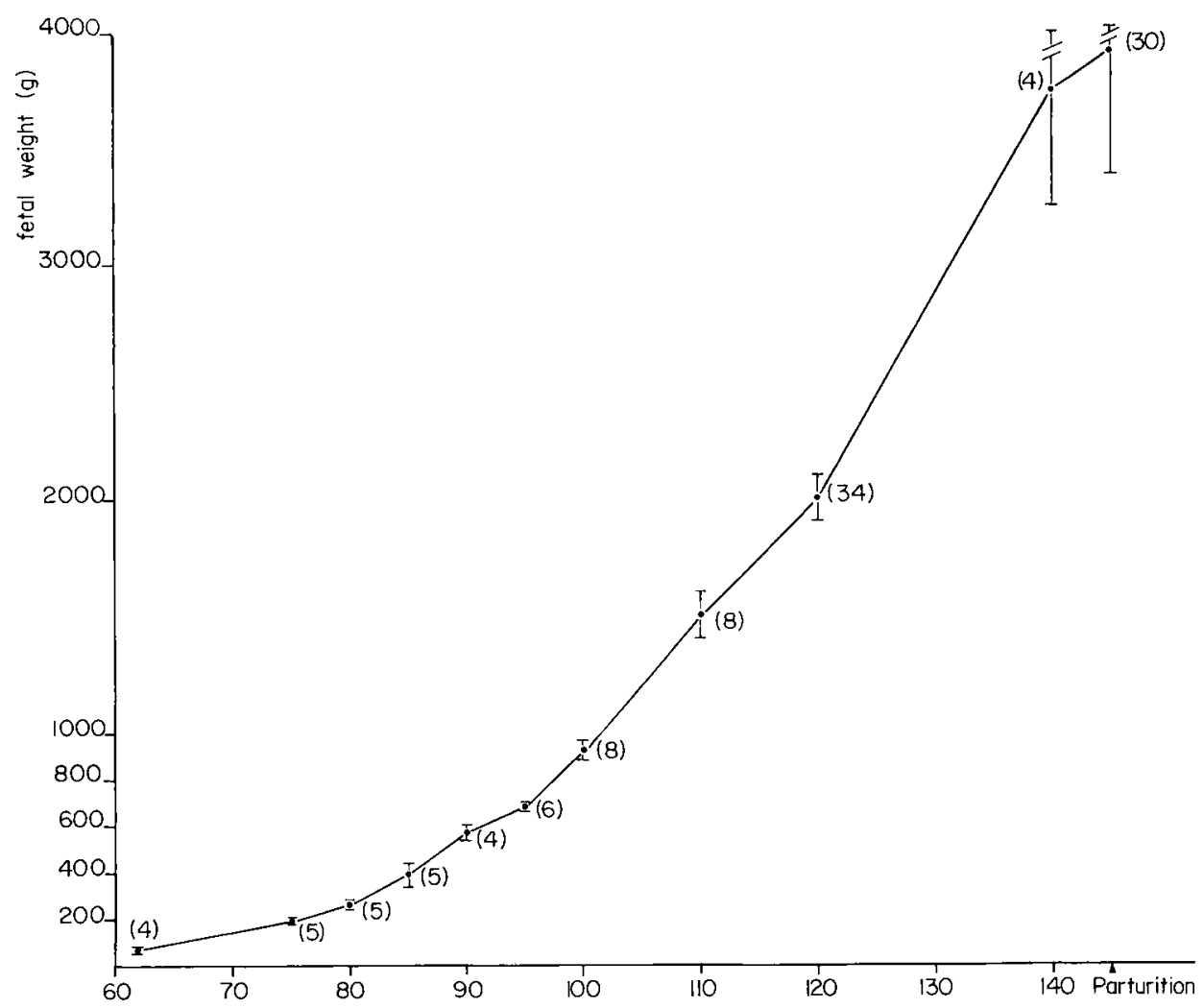

FIG. 4. - Variation in the weight of a lamb foetus from day 60 of gestation to parturition in a Préalpes du Sud ewe

Chlorpromazine, a dopaminergic antagonist, does not alter serum oCS concentration in the ewe either (Mc Millen et al., 1977).

All these results indicate that oCS production is not regulated through dopaminergic pathways. Somatostatin is known to depress the hypophyseal secretion of growth hormones. Infusion of this peptide into ovine foetuses does not apparently modify maternal and foetal oCS plasma levels (Taylor et al., 1983).

\section{Placenta and oCS.}

The importance of placenta in foetal growth, though implicit, has been demonstrated by Robinson et al. (1979). Excision of part of the uterine 


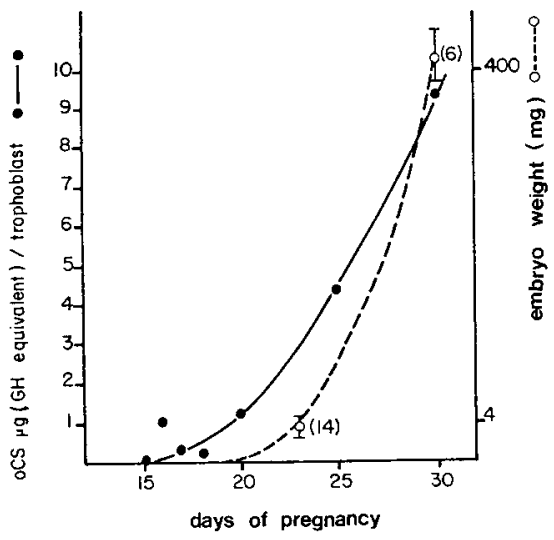

FIG. 5. - Weight gain and oCS content of an ovine embryo between day 15 and 30 of gestation (oCS is measured as oGH equivalent).

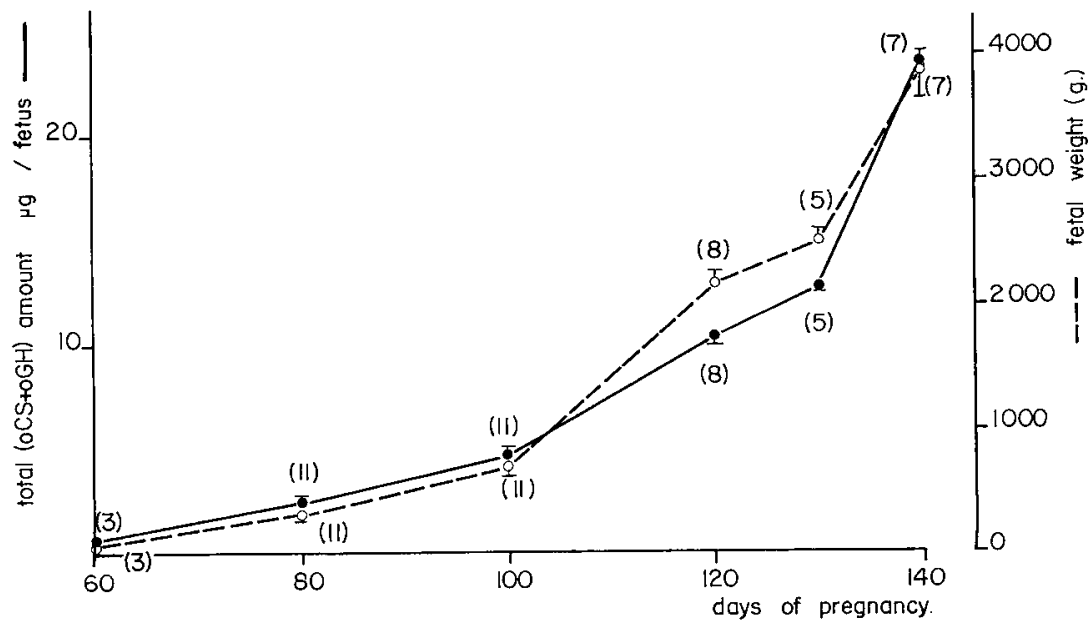

FIG. 6. - Weight gain and total oCS content (oGH + oCS) of an ovine foetus between day 60 and 140 of gestation.

\section{TABLE 1}

Variations of oCS in foetal and maternal blood, measured by radioreceptor assay, after bromocriptine treatment.

\begin{tabular}{ccccccc}
\hline & \multicolumn{3}{c}{ Maternal oCS $(\mathrm{ng} / \mathrm{ml})(1)$} & \multicolumn{2}{c}{ Foetal oCS $(\mathrm{ng} / \mathrm{ml})(1)$} \\
\cline { 2 - 7 } $\begin{array}{c}\text { Days of } \\
\text { gestation }\end{array}$ & $\begin{array}{c}\text { Control ewes } \\
(3)\end{array}$ & $\begin{array}{c}\text { Treated ewes } \\
(3)\end{array}$ & $\begin{array}{c}\text { Significance } \\
(2)\end{array}$ & $\begin{array}{c}\text { Control ewes } \\
(3)\end{array}$ & $\begin{array}{c}\text { Treated ewes } \\
(3)\end{array}$ & $\begin{array}{c}\text { Significance } \\
(2)\end{array}$ \\
\hline $90-95$ & $159 \pm 26(6)$ & $183 \pm 22(7)$ & NS & $146 \pm 17(6)$ & $131 \pm 15(7)$ & NS \\
$110-120$ & $485 \pm 54(7)$ & $461 \pm 60(7)$ & NS & $184 \pm 22(7)$ & $163 \pm 16(7)$ & NS \\
\hline
\end{tabular}

(1) oCS is expressed as prolactin equivalent (PS7 NIH, $24 \mathrm{UI} / \mathrm{mg}$ ); (2) Student's test for the means of two samples; (3) Means \pm standard error (number of animals). 


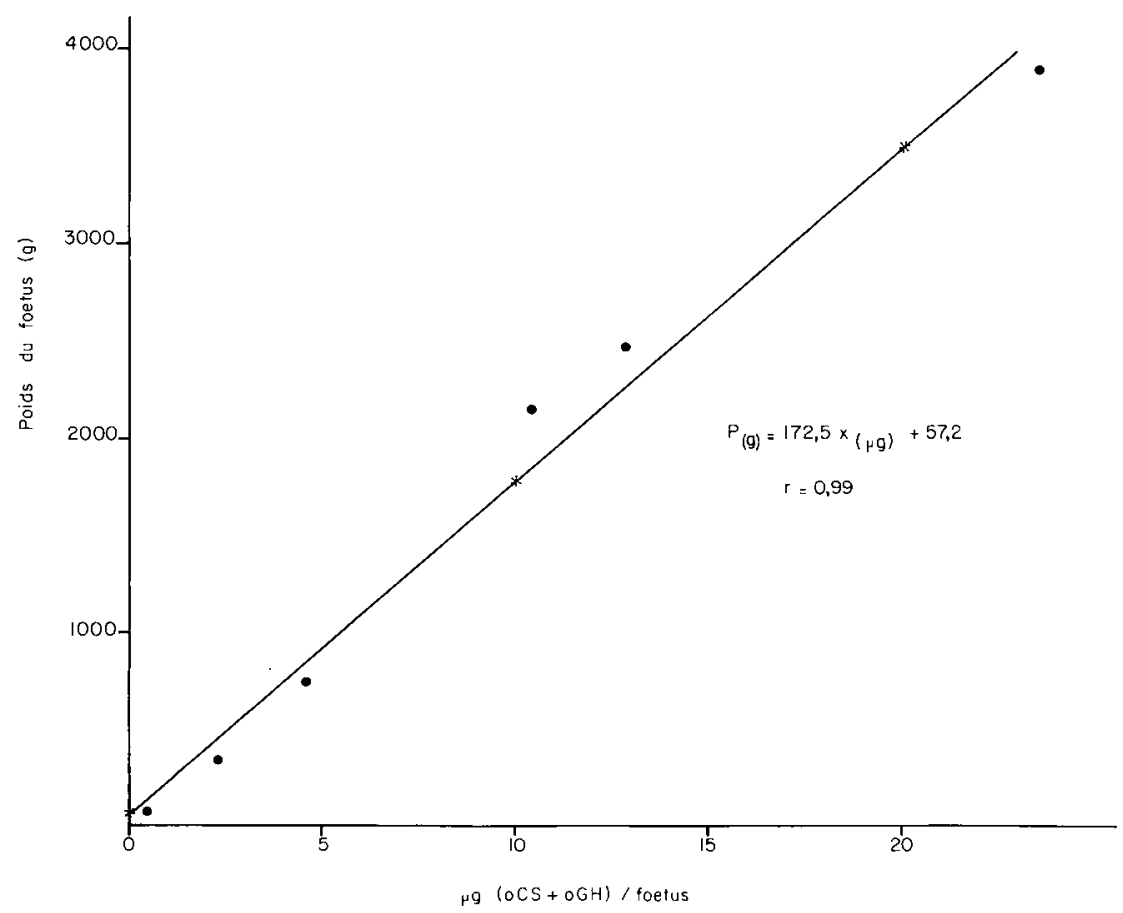

FIG. 7. - Linear relationship between foetal weight and total growth activity (oCS $+\mathrm{OGH})$ per ovine foetus.

caronculae in the ewe before mating leads to a reduction in foetal growth and disturbs foetal metabolism. Figure 11 shows the variation in placental weight and oCS content during gestation (from day 60 to parturition) in Préalpes du Sud ewes. The weight of foetal cotyledons increases up to day 70 of gestation and then remains almost steady until day 140. Just before parturition cotyledon weight drops rapidly. The amount of oCS per $g$ of fresh tissue increases until day 100 to reach a maximum between day 100 and 130 , then falls suddenly until lambing. An asynchrony is observed between oCS production and weight gain of placenta.

\section{Number of foetuses and oCS.}

The oCS concentration per $\mathrm{g}$ of placenta is constant, whatever the number of foetuses (Martal and Djiane, 1977). By contrast, the weight of placenta is proportional to the number of foetuses (Fig. 12). Accordingly, the total amount 


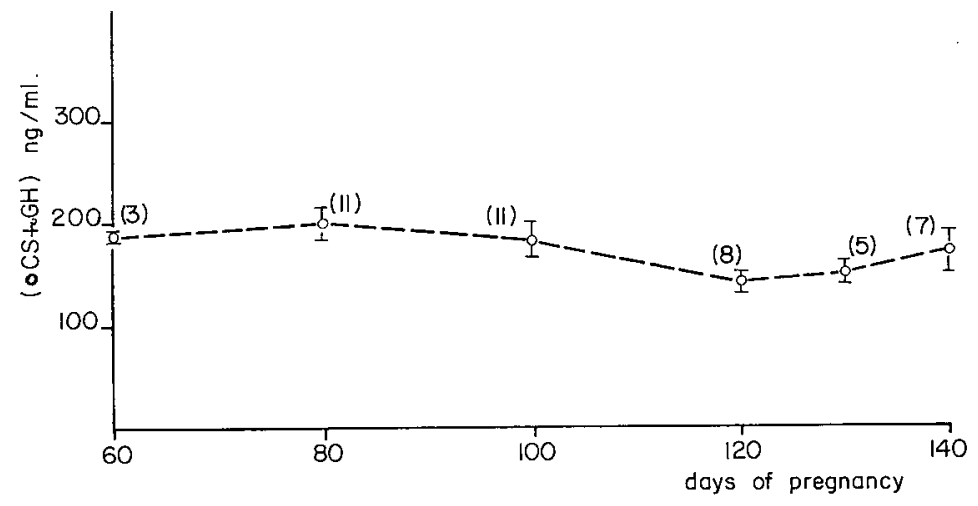

FIG. 8. - Variation in growth hormone concentrations $(\mathrm{oCS}+\mathrm{oGH})$ of the ovine foetus during gestation.

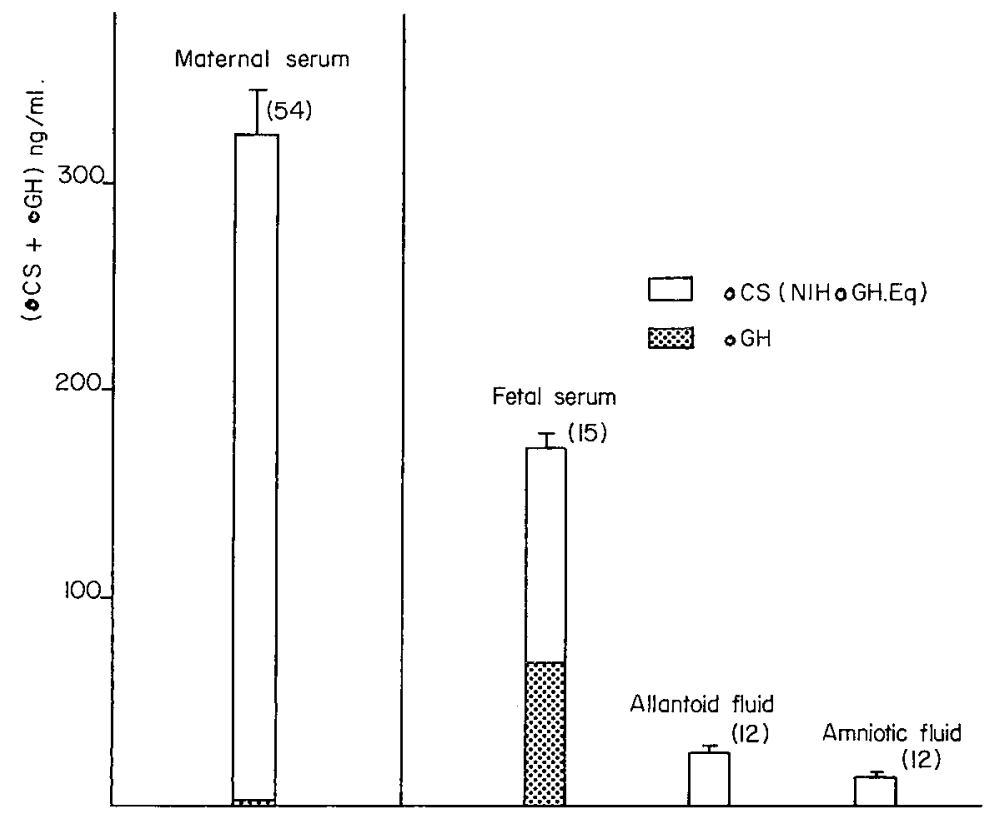

FIG. 9. - Comparison of total growth activities (oCS $+\mathrm{oGH}$ ) between maternal and foetal fluids on day 120 of gestation in the ewe.

of oCS in maternal blood is also higher in twin gestation (Fig.13). oCS determination in maternal serum may allow the diagnosis of twin pregnancy (Table 2). 


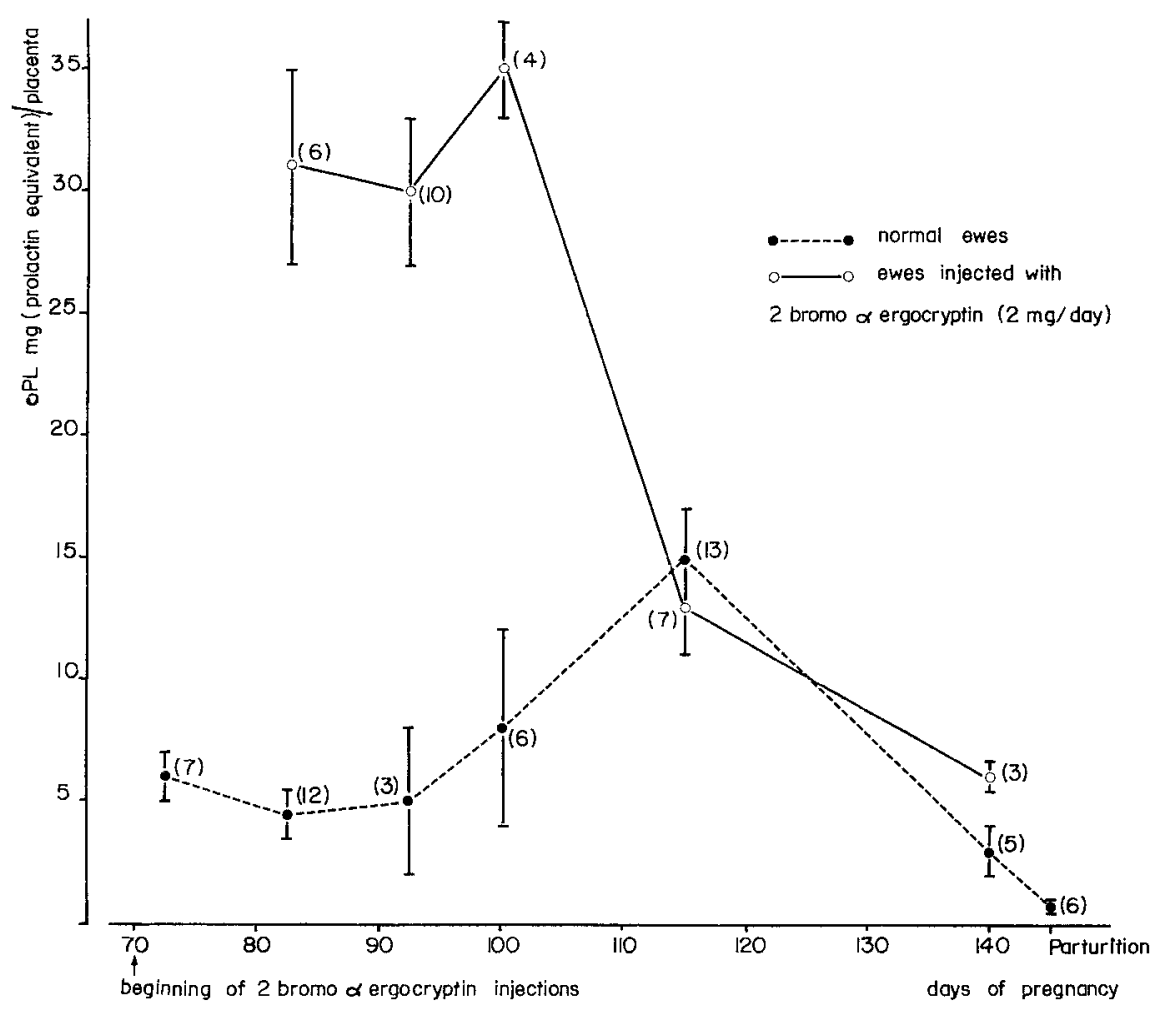

FIG. 10. - Variations in placental oCS between normal and bromocriptine-treated ewes.

\section{Anti-oCS antibodies and growth.}

Up to now, it is not possible to inhibit totally oCS production without damaging the embryonic survival. Waters et al. (1985) have tried to evade the problem by using anti-oCS antiserum. A $12 \mathrm{~h}$-infusion of these antibodies to ewes on day 131 of gestation, in sufficient amounts to neutralize circulating oCS, does not affect the weight of lambs at birth compared to those of control ewes (perfused with goat $\gamma$ globulins). These results are inconsistent with the growth promoting activity of oCS for the following reasons. First, the injection was performed in late gestation. At this stage the foetal pituitary is totally functional. Second, the length of perfusion ( $12 \mathrm{~h}$ ) was too short. It should be mentioned that during these experiments the IGF-I, IGF-II and GH plasma levels did not change.

\section{oCS receptors.}

oCS receptors have been evidenced by Chan et al. (1978) in several ovine tissues. The highest binding activity of oCS $(\simeq 30 \%)$ has been obtained in the maternal liver and fatty tissue. Nevertheless, oCS binds poorly to mammary 


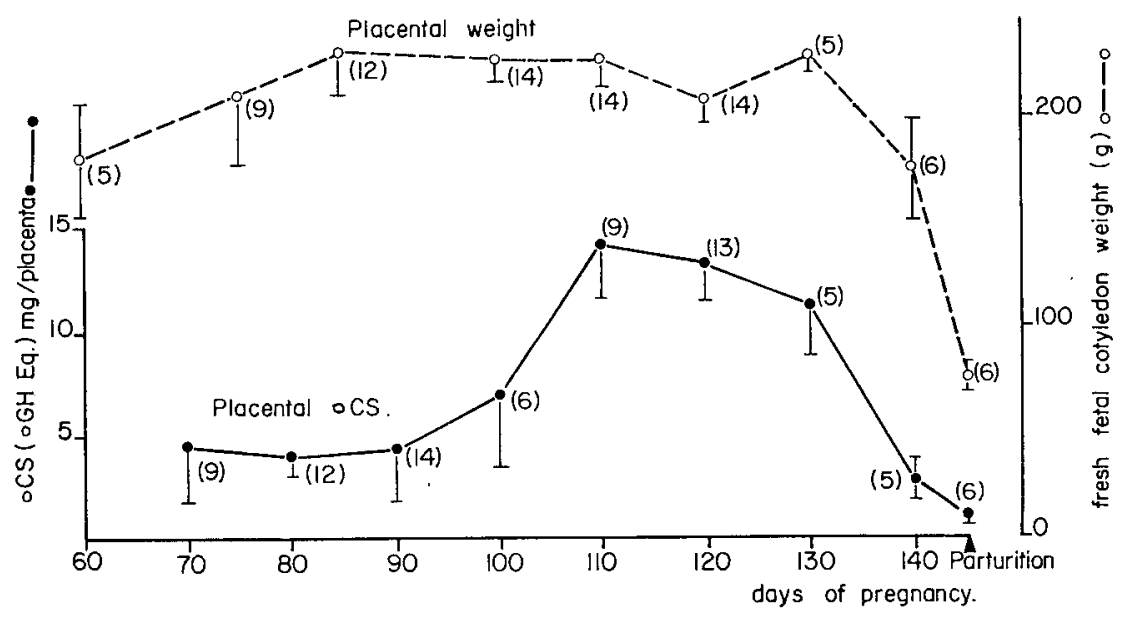

FIG. 11. - Variations in placenta weight and placental oCS concentration (expressed as oGH equivalent) in a single foetus ewe.

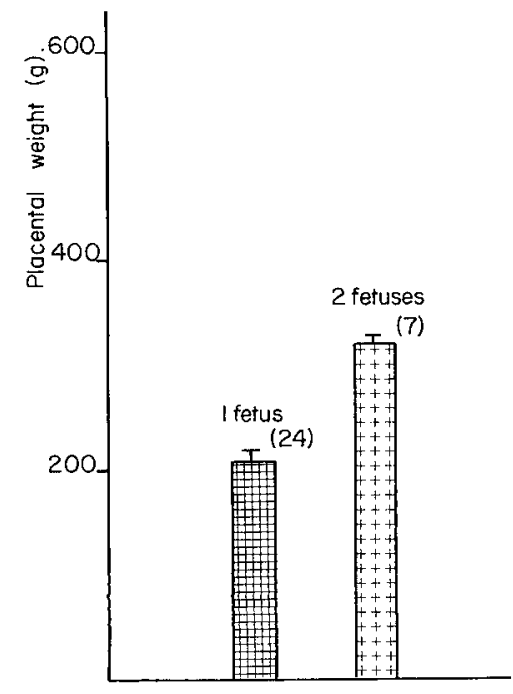

FIG. 12. - Variation in the placenta weight of a ewe on day 125 of gestation according to the number of foetuses.

receptors $(\simeq 3 \%)$ whereas it has a prolactin-like effect in rabbits (Martal and Djiane, 1975 ; Chan et al., 1976). Similar results have been obtained by N'Guema Emane et al. (1986) who confirm the presence of oCS specific receptors in the liver of pregnant or non-pregnant ewes. The liver is considered as the main target for oCS in sheep, while mammary gland receptors bind oCS very poorly in pregnant or lactating ewes. Moreover, the existence of specific oCS high-affinity 


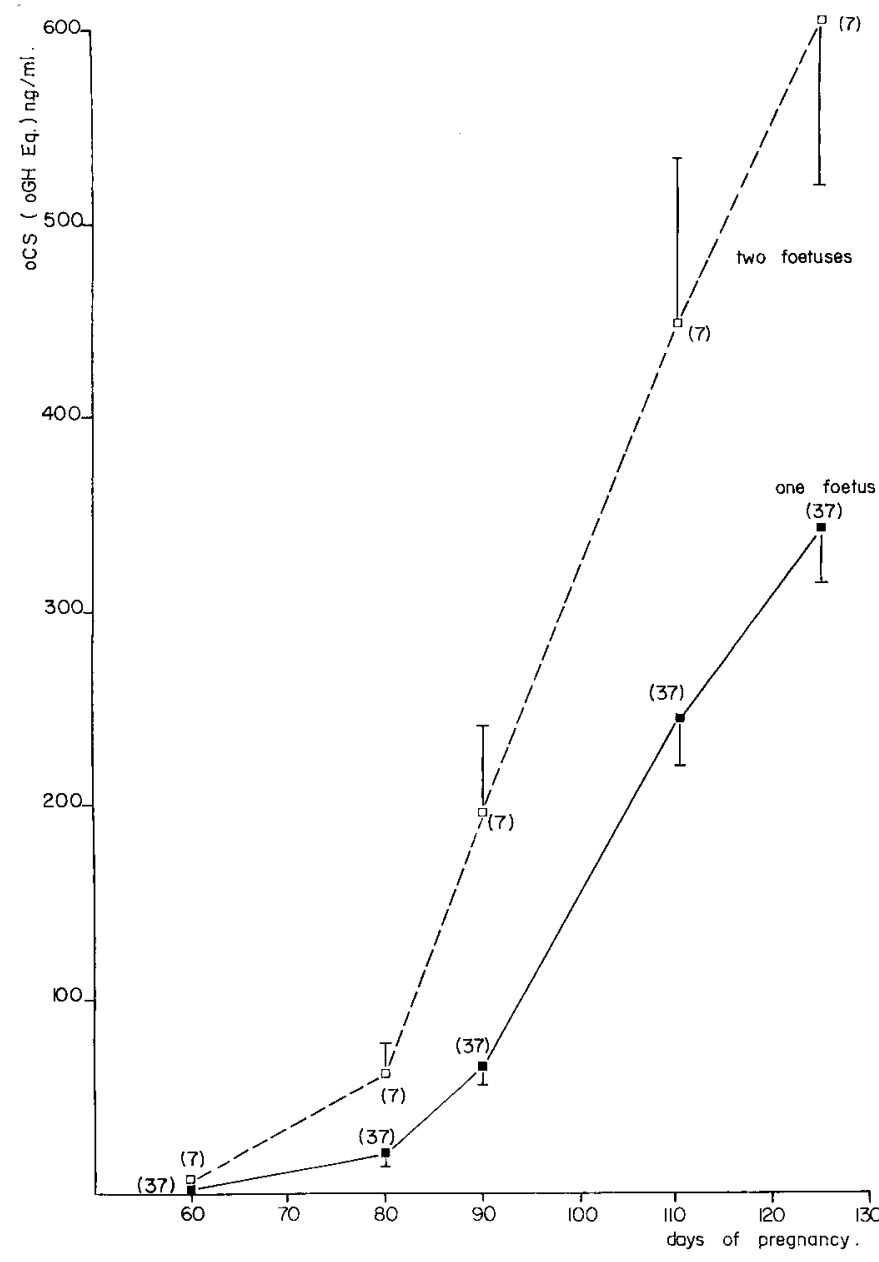

FIG. 13. - Serum oCS concentration (expressed as OGH equivalent) during gestation in a single or twin foetus ewe.

receptors in the liver of a lamb foetus (day 140 of gestation) has been demonstrated by Freemark et al. (1987), whereas homologous hormones (oGH and $O P R L$ ) have a very low affinity for foetal liver membranes. Foetal and maternal ovine livers are thus target organs for oCS.

\section{Somatomedins and oCS.}

As oCS is involved in growth, it may be wondered whether its action is similar to that of growth hormone.

It is well known that one property of oCS is to bind to adult liver membranes. It may be assumed that the growth activity of oCS is associated with stimulation of somatomedins. This hypothesis was confirmed by Hurley et al. (1977a). Serum 
Twin gestation diagnosis by oCS determination using radioreceptor assay (oCS $+o G H)$ on day 110 of gestation.

\begin{tabular}{lc}
\hline Number of tested ewes & $376(1)$ \\
Number of presumed one-lamb ewes & 202 \\
Number of real one-lamb ewes at birth (2) & 203 \\
Number of inversions (twin taken for single) & 15 \\
\hline Diagnosis accuracy for one-lamb ewes (3) & $92 \%$ \\
\hline Number of presumed twin & 147 \\
Number of real twin (2) & 146 \\
Number of inversions (twin taken for single) & 14 \\
\hline Accuracy of gestation diagnosis for twin ewes (3) & $90 \%$ \\
\hline
\end{tabular}

(1) Ewes selected as pregnant on day 19 by determination of serum progesterone levels (test accuracy : $94 \%)$.

(2) Control at lambing: ewes with stillborn and aborted lambs are included in this table.

(3) Number of accurate diagnoses/Total number of diagnoses $\times 100$.

somatomedin- $\mathrm{C}$ concentrations, measured by radioimmunoassay or by radioreceptor assay, increase after injection of oCS and $\mathrm{bGH}$ in hypophysectomized adult rats. Moreover, carunclectomy of ewes before pregnancy lowers plasma somatomedin concentration (Falconer et al., 1977). In the foetus, somatomedin secretion might be mediated by oCS. The following observations confirm this hypothesis.

Both types of insulin-like growth factors have been determined in the blood of ovine foetus between day 54 of gestation and birth and in newborn lambs. IGF-I concentrations measured by radioimmunoassay are very small throughout pregnancy (about one third of the concentration in adults). IGF-I concentrations increase just after birth when growth becomes GH-dependent (Gluckman and Butler, 1983 ; van Vliet et al., 1983). By contrast, foetal IGF-II concentrations are higher than in adults at least from day 60 to $72 \mathrm{~h}$ before delivery. They fall rapidly at birth to reach the values of adult sheep (Gluckman and Butler, 1983). IGF-I and IGF-II secretions are not correlated in the ovine foetus. However, there seems to be a relationship between oCS and IGF-II levels during pregnancy (Lowe et al., 1982). IGF-II secretion is predominant during foetal growth. This factor is secreted by foetal liver explants in rats (Rechler et al., 1979) as well as by embryonic fibroblasts (Adams et al., 1983b). Moreover, only oCS, and not hGH can stimulate IGF-II production by fibroblasts from newborn rats but cannot stimulate fibroblasts from older rats. oCS and hGH induce IGF-I production by fibroblasts from adult rats (Adams et al., 1983a). Many foetal tissues (liver, lung, brain, heart, intestine, kidney) in mice (D'Ercole et al., 1980) and lungs in man (Snyder and D'Ercole, 1980) have been found to synthesize in vitro IGF-I. Rat placenta does not produce IGF-I (D'Ercole et al., 1980). By contrast, IGF-II receptors have been detected in the placenta of ewe (day 90 of gestation), and 
were used for IGF-II determination by a radioreceptor assay (Baxter and De Mellow, 1986). After 4-day oGH infusion to foetuses of hypophysectomized lambs (between days 103 and 114), Parkes and Hill (1985) did not notice delayed growth or weight variation in either hypophysectomized animals or controls after delivery or a change in the plasma IGF-I concentrations in animals infused or not with oGH. Only a slight delay in bone development was observed in hypophysectomized lambs. These authors have confirmed that foetal pituitary is not involved in foetal growth and that IGF-I is not GH-dependent. By contrast, IGF-I is GH-dependent in adults.

\section{GRF and TRH effects on late ovine and bovine foetal growth.}

Subcutaneous injections of GRF (growth hormone releasing factor) to ewes in late gestation increase the birth weight of lambs. This effect persists after birth (G. Kann, personal communication). According to Barlet (1988a), «it seems logical to think that GRF administration to pregnant female can stimulate foetal growth by a double process resulting from an increased $\mathrm{GH}$ secretion. On the one hand, GH would increase food efficiency, which improve the availability of nutriments for the foetus. On the other hand, this effect could be enhanced by a stimulating effect of $\mathrm{GH}$ on placental blood flow ". The same author reported that direct intravenous injections of 1-29 GRF in male calf foetus at days 220, 250 and 270 of gestation increased the mean birth weight from $48.2 \mathrm{~kg}$ in controls to $51.4 \mathrm{~kg}$ in treated animals and that this difference persisted for 3 weeks. Such a growth improving effect was attributed to an increased IGF-I plasma level (Barlet, 1988a).

Not only GRF but also TRH treatment can induce a growth effect (Barlet, $1988 \mathrm{~b})$. Subcutaneous injections of TRH in pregnant heifers at days 230, 240, 250 and 265 of gestation resulted in higher birthweight $(+10 \%)$ and higher daily weight gain for 120 days after birth in newborn treated calves than in controls. TRH treatment significantly increased plasma T3, GH and IGF-I in term cows and plasma IGF-I concentrations in newborn calves. The growth-promoting effect of the TRH treatment was attributed to increased IGF-I levels (Barlet, 1988b).

\section{Foetal growth and $\mathrm{hPL}$.}

Although hPL does not bind to somatotropic receptors (Tsushima and Friesen, 1973) and despite a similar structure between hGH and hPL.(Li et al., 1971, 1972), hPL possesses a significantly lower somatotropic activity than hGH. Weight gain stimulation in hypophysectomized immature male rats requires higher levels of hPL than of hGH (Florini et al., 1966). Furlanetto et al. (1978) have reported a correlation between maternal $\mathrm{hPL}$ and somatomedin concentrations in pregnant women. The ability of hPL to increase IGF-I content and its release from foetal pancreatic explants has been shown recently by Swenne et al. (1987), and hPL might participate at least in foetal pancreatic development. 
The direct involvment of hPL in human foetal growth has not yet been demonstrated. Nielsen et al. (1979) have shown that even with very weak levels of hPL (less than $25 \mathrm{ng} / \mathrm{ml}$ ) in the maternal blood, foetal development progresses normally during gestation.

\section{Structure-function relationships of growth-promoting hormones.}

Some of the main placental hormones such as human, rat and mouse placental hormones have a predominant lactogenic activity. Others such as placental hormones of ruminants have both lactogenic and growth activity.

These differences in hormonal activities have led us to investigate more thoroughly the structure-function relationships of these hormones. In this respect, we will refer to works dealing with hCS or hPL and hGH, the better known hormones. Indeed, it is strange that two hormones, hGH and hPL, exhibiting a similar amino acid content ( $85 \%$ ) and a $96 \%$ homology are endowed with different activities. hGH possesses a lactogenic and growth promoting activity and hPL only lactogenic activity, not growth activity (at least in terms of binding to somatotropic receptors). The works of Russell et al. (1981) who have used hybrids of these two molecules after plasmin action, and tested their binding capacity to lactogenic and growth receptors have contributed to a better understanding of this matter. On the one hand, the $\mathrm{NH}_{2}$-terminal peptide of hGH (1-134) linked by a disulfide bridge to the $\mathrm{COOH}$-terminal peptide of $\mathrm{hPL}$ (141-191) binds to mammary gland or liver receptors. On the other hand, the recombinant obtained by linking the $\mathrm{NH}_{2}$-terminal part of $\mathrm{hPL}(1-134)$ to the $\mathrm{COOH}$-terminal part of hGH (141-191) displays only lactogenic activity. So, only the $\mathrm{NH}_{2}$-terminal fragment $(1-134)$ possesses specific somatotropic activity.

In vivo, the $\mathrm{NH}_{2}$-terminal fragment of $\mathrm{hGH}(1-134)$ connected to the (141-191) fragment of hPL (Li, 1978) elicits $50 \%$ growth activity as compared to a homologous hGH recombinant (1-134) (141-191) (Li et al., 1977). The reduced activity could be attributed to the substitution, in the last third of this molecule of aspartic acid in position 153 and isoleucine in position 179 for $\mathrm{hGH}$, and of histidine and methionine respectively for hPL (Fig. 14).

A hGH molecule deprived of 135-145 peptide also exhibits a growth activity (Singh et al., 1974). Thus, this peptide can be assimilated to a neutral part for growth activity. Thanks to chemical modifications particularly affecting basic amino acids, some authors have attributed to lysine or arginine at positions 16, 41, $64,70,77,115$ and 134 , a participation in the hormone-liver receptor interaction (Martal et al., 1985 ; Chêne et al., 1989). A study of the hydropathy profiles of hPL and hGH by Nicoll et al. (1986) has shown differences in two parts, (59-76) and (100-117). Analysis of the amino acid composition of these two hormones and other GHs reveals that four amino acids (methionine 64, aspartic acids 104 and 110, and histidine 112) could contribute to the absence of growth activity in the hPL molecule (Chêne et al., 1989). Unfortunately, at present, only human placental hormone ( $h P L$ ) can be compared with growth promoting hypophyseal hormones when determining the biological sites of growth activity since the 


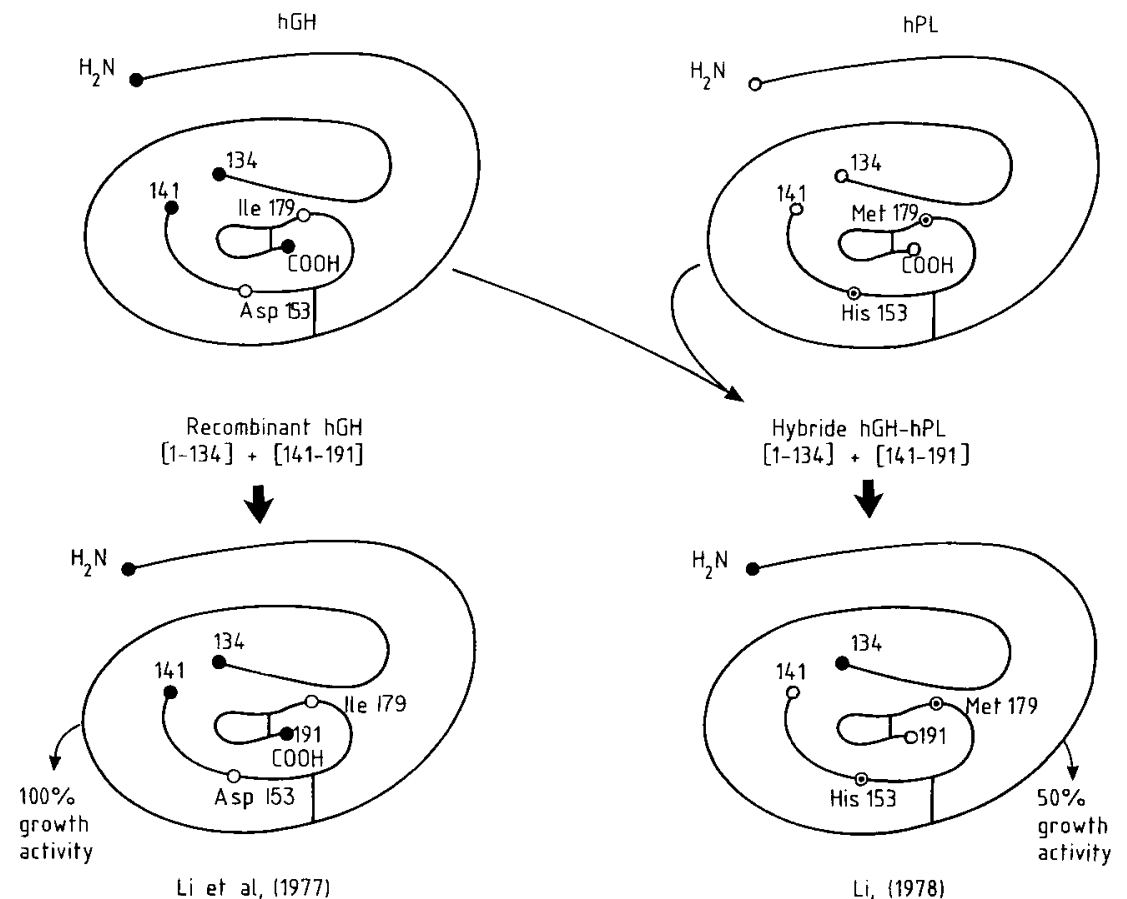

FIG. 14. - Evidence for one amino acid (at position 163) in hPL inhibiting growth bioactivity (measured by rat tibia test) and related to $h G H$ and $h P L$ peptide recombinants.

sequences of placental hormones in ruminants have not been established yet. Only the sequences of placental hormones in rats (Duckworth et al., 1986) and mice (Jackson et al., 1986) have been elucidated. They are not endowed with growth activity and are much more closely related to prolactins of the same species. Figure 15 summarizes the main sites of growth activity.

Nevertheless, our knowledge of structure-function relationships in terms of growth activity will be improved by further studies on the primary structures of placental hormones.

\section{Growth factors.}

Foetal growth seems to be very complex and controlled by many factors such as foetal genome; it also seems to depend on maternal potential such as size and nutrient and oxygen supplies. Besides, other hormones than CS may intervene in foetal growth: human placental growth hormone (Hennen et al., 1985), proliferine (Linzer and Nathans, 1984), thyroid hormones (Thorburn, 1974; Nathanielsz, 1976), insulin and its related peptides, the insulin-like growth factors (IGFs) reviewed by Milner and Hill (1984), oestrogens which exert an inhibitory effect on placental weight and further on foetal weight (Abdul-Karim et al., 1971). Other peptidic factors have a growth stimulating activity. The following list is not exhaustive. 


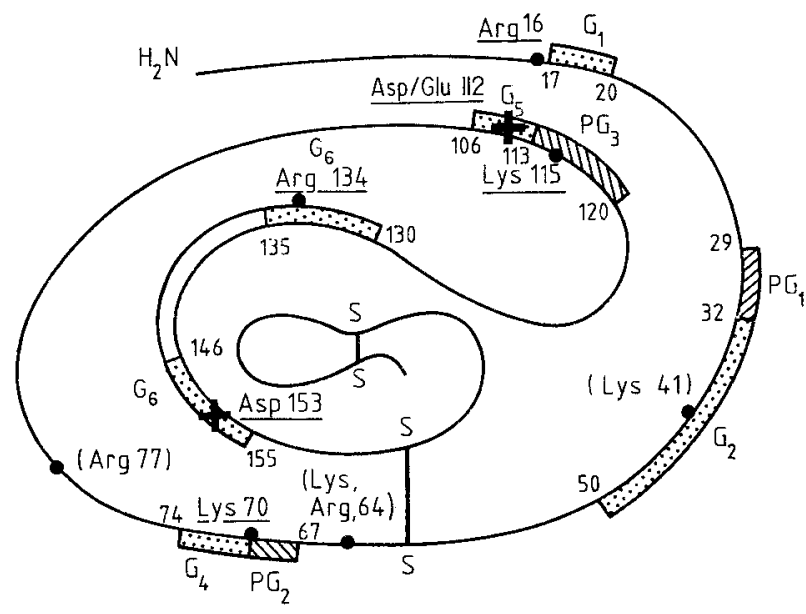

FIG. 15. - Model to localize biological sites in growth hormones according to the studies of Nicoll et al. (1986), Martal et al. (1985) and Chêne et al. (1988)

$\because \mathrm{G}:$ Growth hormone binding determinants; $\mathrm{PG}$ : Prolactin and growth hormone binding determinants ; $a a$ : Basic amino acids involved in growth activity ; (aa) : Basic amino acids excluded from growth activity; $X$ : Acidic amino acids involved in growth activity; 135-145: Inactive peptide in growth activity (according to Graf et al., 1982).

Epidermal growth factor (EGF), nerve growth factor (NGF), platelet-derived growth factor (PDGF), transforming growth factors (TGFs), fibroblast growth factors and oncogen-derived proteins are among the principal growth factors studied by Evain-Brion in this book (1988).

Finally, very complex foetal growth implies cellular multiplication and differentiation but also modelling of tissues and organs.

All these mechanisms depend on genetic and nutritional elements (not studied here), on classical endocrine regulation and obviously on growth factors (GFs endocrine or paracrine peptides). This foetal growth is regulated by other hormones than those involved in post-natal growth. For instance, pituitary hormones which are essential to newborn growth, intervene little or not at all in the foetus. The placenta prevents the flow of maternal peptidic hormones (pancreatic and hypophyseal). However, Obregon et al. (1984) have suggested that thyroid hormones cross the placental barrier. On the whole, maternal hormonal in ruminants secretions activate metabolism by supplying nutrients and enhance blood flow to ensure normal gestation (Kalkhoff and Kim, 1979). For foetal development, the placenta functions independently. Ovine foetal pituitary growth hormone is not essential to foetal growth (Liggins and Kennedy, 1968), whereas ovine foetal thyroid hormone seems to affect it positively (Thorburn, 1974).

Foetal growth is stimulated by insulin and its related peptides (Hill and Milner, 1985). Pancreatectomy of a 3-week-old lamb foetus provokes a weight reduction by about $20 \%$ (Fowden and Comline, 1984). Many growth factors are 
involved in cellular multiplication and differentiation; some of them are hormonedependent such as IGF-I. They can act on adjacent cells (paracrine) or on the cell that secretes them (autocrine). Some growth factors are interdependent.

The main characteristic of foetal growth in ruminants, and particularly in ewes, is the existence of a placental lactogen hormone also endowed with growth promoting activity. In other species this hormone is either absent or present, but also endowed with lactogenic activity (for example hPL). In man, another placental hormone (hPGH) could elicit growth activity, thus replacing hPL. The structural characteristics of oCS have not been elucidated yet, whereas its biological effects are relatively well known. The studies conducted on this hormone emphasize its not exclusive but important implication in foetal growth in sheep.

$27^{e}$ Réunion de la Société française pour l'Etude de la Fertilité Paris, 29, 30 sept., $1^{\text {er }}$ oct. 1988

Acknowledgements. - We are grateful to Mrs A. Bouroche for the translation of this text into English.

Résumé. Somatomammotropine chorionique ovine (oCS) et croissance fœtale.

Une hormone d'origine placentaire, la somatomammotropine chorionique ovine (oCS), stimule la croissance pondérale et osseuse de rats hypophysectomisés. Elle possède une bifonctionnalité : somatotrope et lactogène puisqu'elle se lie à des récepteurs soit d'origine hépatique, soit d'origine mammaire. La croissance pondérale du fotus ovin est étroitement liée à la quantité totale d'oCS et d'hormone de croissance ovine (oGH) sérique. L'oCS stimule la production de somatomédines par le foie fœetal. L'existence de récepteurs spécifiques à l'oCS dans les tissus fœtaux affirme le rôle de l'oCS dans la croissance fœtale tandis que l'hormone de croissance hypophysaire est plus impliquée dans la croissance postnatale. Une étude des relations structure-fonction d'hormones est entreprise afin de localiser les sites responsables de l'activité de croissance. Différentes hormones ou facteurs qui participent à la croissance sont également mentionnés dans ce texte.

\section{References}

ABDUL-KARIM R. W., NESBITT R. E. L. Je., DRUCKER M. H., RIZK P. T., 1971. The regulatory effect of oestrogens on fetal growth. 1. Placental and fetal body weights. Am. J. Obstet. Gynec., 109, 656-661.

ADAMS S. O., NISSLEY S.P., HANDWERGER S., RECHLER M. M., 1983a. Developmental patterns of insulin-like growth factor-I and II synthesis and regulation in rat fibroblasts. Nature, Lond., 302, 150-152.

ADAMS S.O., NISSLEY S.P., GREENSTEIN L. A., YANG Y.M. H., RECHLER M.M., 1983b. Synthesis of multiplication-stimulating activity (rat insulin-like growth factor) by rat embryo fibroblasts. Endocrinology, 112, 979-987.

ALEXANDER D. P., BRITTON H. G., NIXON D. A., 1966. Observation on the isolated foetal sheep with particular reference to the metabolism of glucose and fructose. J. Physiol. Lond., 185. $382-399$.

BARLET J.P., 1988a. La thyrolibérine injectée à la vache gestante augmente le poids de naissance et stimule la croissance postnatale des veaux. C.R. Acad. Sci., Paris, 306, 511-514.

BARLET J. P., 1988b. GRF et croissance fotale. Biofutur, 69, 96-97. 
BASSETT J.M., THORBURN G. D., WALLACE A. L. C., 1970. The plasma growth hormone concentration of the foetal lamb. J. Endocr., 48, 251-263.

BAXTER R. C., DE MELLOW J.S.M., 1986. Measurement of insulin-like growth factor-ll by radioreceptor assay using ovine placental membranes. Clin. Endocrinol., 24, 267-278.

BECK P., DAUGHADAY W. H., 1967. Human placental lactogen : studies of its acute metabolic effects and disposition in normal man. Endocrinology, 46, 103-109.

BOSHIER D.P., 1969. A histological and histochemical examination of implantation and early placentome formation in sheep. J. Reprod. Fert., 19, 51-61

BREWER D. B., 1957. Congenital absence of the pituitary gland and its consequences. J. Path. Bact., 73, 59-67.

BRINSMEAD M.W., WATERS M.T., THORBURN G. D., 1980. Placental lactogen and fetal growth, 457-460. In CUMMING I. A., FUNDER J. W., MENDELSOHN F. A. O., Endocrinology Austr. Acad. Sci., Canberra.

BUTLER S. R., HURLEY T. W., SCHANBERG S. M., HANDWERGER S., 1978. Ovine placental lactogen stimulation of orn ithine decarboxylase activity in brain and liver of neonatal rats. Life Sci., 22, 2073-2078.

CARIDAD J. J., WOLFENSTEIN-TOFEL C., 1988. Selective reduction of the disulfide bonds of ovine placental lactogen. Int. J. Peptide Protein Res., 31, 71-76.

CHAN J.S. D., NIE Z. R., SEIDAH N. G., CHRETIEN M., 1986. Purification of ovine placental lactogen (oPL) using high-performance liquid chromatography. FEBS, 199, 259-264.

CHAN J.S. D., ROBERTSON H. A., FRIESEN H. G., 1976. The purification and characterization of ovine placental lactogen. Endocrinology, 98, 65-76.

CHAN J. S. D., ROBERTSON H. A., FRIESEN H. G., 1978. Distribution of binding sites for ovine placental lactogen in the sheep. Endocrinology, 102, 632-640.

CHÊNE N., 1987. Relations structure-fonction d'hormones à activités lactogène et de croissance en vue d'applications à l'étude de la somatomammotropine chorionique ovine (oCS). Thèse de Doct. Univ., $40 \mathrm{p}$.

CHÊNE N., MARTAL J., DE LA LLOSA P., CHARRIER J., 1989. Growth hormones. II structure-function relationships. Reprod. Nutr. Dévelop., 29, in press.

CHO D. Y., LEIPOLD H. W., 1978. Anencephaly in calves. Cornell. Vet., 68, 60-69.

CONTOPOULOS A. N., SIMPSON M. E., 1959. Growth promoting activity of pregnant rat plasma after hypophysectomy and after thyroidectomy. Endocrinology, 64, 1023-1031.

D'ERCOLE A. J., APPLEWHITE G. T., UNDERWOOD L. E., 1980. Evidence that somatomedin is synthesized by multiple tissues in the fetus. Develop. Biol., 75, 315-328.

DUCKWORTH M. L., KIRK K. L., FRIESEN M. G., 1986. Isolation and identification of a cDNA clone of rat placental II. J. biol. Chem., 261, 10871-10878.

EREZ S., KING T. M., 1966. Anencephaly : a survey of 44 cases. Obstet. Gynec., 27, 601-604.

EVAIN-BRION D., 1988. Facteurs de croissance et développement embryonnaire. Reprod. Nutr. Dévelop., 28, $1681-1686$.

FALCONER J., FORBES J. M., HART I. C., ROBINSON J. S., THORBURN G., 1977. Somatomedin activity in foetal sheep following hypophysectomy or after reduction of placental size by removal of endometrial caruncles. J. Physiol., 272, $18 \mathrm{p}$.

FLORINI J. R., TONELLI G., BREUER C. B., COPPOLA J., RINGLER I., BELL P. H., 1966. Characterization and biological effects of purified placental protein (human). Endocrinology, 79 , $692-708$.

FOWDEN A., COMLINE R. S., 1984. The effect of pancreatectomy on the sheep fetus in utero. $Q$. J. exp. Physiol., 69, 319-330.

FREEMARK M., COMER M., KORNER G., HANDWERGER S., 1987. A unique placental lactogen receptor: implications for fetal growth. Endocrinology, 120, 1865-1872.

FREEMARK M., HANDWERGER S., 1982. Ovine placental lactogen stimulates amino-acid transport in rat diaphragm. Endocrinology, 110, 2201-2203.

FURLANETTO R. W., UNDERWOOD L. E., Van WYK J. J., HANDWERGER S., 1978. Serum immunoreactive somatomedin $\mathrm{C}$ is elevated in late pregnant. J. clin. Endocrinol. Metab., 47, 695-697.

GLUCKMAN P. D., BUTLER J. H., 1983. Parturition related changes in insulin like growth factor-I and - II in perinatal lamb. J. Endocr., 99, 223-232. 
GRAF L., LI C. H., JIBSON M. J., 1982. Human somatotropin. Selection removal with trypsin of residues 135-145 from the hormone molecule with no loss of biological activities. J. biol. Chem., 257, 2365-2369.

GRUMBACH M. M., KAPLAN S. L., SCIARRA J. J., BURR I. M., 1968. Chorionic growth hormone prolactin (CGP) : secretion, disposition, biologic activity in man, and postulated as the "growth hormone" of the second half of pregnancy. Ann. New York Acad. Sci., 148, $501-531$.

HANDWERGER S., FELLOWS R. E., CRENSHAW M. C., HURLEY T., BARRETT J., MAURER W. F., 1976. Ovine placental lactogen : acute effects on intermediary metabolism in pregnant and non-pregnant sheep. J. Endocr., 69, 133-137.

HANDWERGER S., MAURER W., BARRETT J., HURLEY T., FELLOWS R. E., 1974 . Evidence for homology between ovine and human placental lactogens. Endocrine Res. Commun., 1, 403-413.

HENNEN G., FRANKENNE F., CLOSSET J., GOMEZ F., PIRENS G., EL KHAYAT N., 1985. A human placental GH : increasing levels during second half of pregnancy with pituitary GH suppression as revealed by monoclonal antibody radioimmunoassays. Int. J. Fertil., 30, 27-33.

HILL D. J., MILNER R. D. G., 1985. Insulin as a growth factor. Pediatr. Res., 19, 879-886.

HURLEY T. W., D'ERCOLE A. J., HANDWERGER S., UNDERWOOD L. E., FURLANETTO R. W., FELLOWS R. E., 1977a. Ovine placental lactogen induces somatomedin : a possible role in fetal growth. Endocrinology, 101, 1635-1638.

HURLEY T.W., GRISSOM F. E., HANDWERGER S., FELLOWS R. E., 1977b. Purification and partial characterization of the cyanogen bromide fragment of ovine placental lactogen. Biochemistry, 16, 5605-5609.

HURLEY T. W., KUHN C. M., SCHANBERG S. M., HANDWERGER S., 1980. Differential effects of placental lactogen, growth hormone and prolactin on rat liver ornithine decarboxylase activity in the perinatal period. Life Sci, 27, 2269-2275.

HURLEY T. W., MAURER W., HANDWERGER S., FELLOWS R. E., 1975. Ovine placental lactogen : structural and functional relationship with growth hormone and prolactin, 583-588. In WALTER R., MEIENHOFER J., Peptides : chemistry, structure and biology. Michigan Ann. Arbor Sci. Publ.

JACKSON L. L., COLOSI P., TALAMANTES F., LINZER D. I. H., 1986. Molecular cloning of mouse placental lactogen cDNA. Proc. nat. Acad. Sci. USA, 83, 8496-8500.

JOST A., 1947. Expériences de décapitation de l'embryon de lapin. C.R. Acad. Sci. Paris, 225, 322-324.

KALKHOFF R. K., KIM H. J., 1979. The influence of hormonal changes of pregnancy on maternal metabolism, 29-56. In BEARD R. W., HOET J. J., Pregnancy metabolism, diabetes and the fetus, Ciba Found. Symp. 63, Excerpta med., Amsterdam.

LI C. H., 1978. Noncovalent interaction of the $\mathrm{NH}_{2}$-terminal fragment of human somatotropin with the $\mathrm{COOH}$-terminal fragment of human chorionomammotropin to generate growth-promoting activity. Proc. nat. Acad. Sci. USA, 75, 1700-1702.

LI C. H., BEWLEY T. A., BLAKE J., HASHIDA T., 1977. Human somatotropin : restoration of full biological activity by non covalent interaction of a natural and a synthetic fragment of the hormone. Proc. nat. Acad. Sci. USA, 74, 1016-1019.

LI C. H., DIXON J.S., CHUNG D., 1971. Primary structure of the human chorionic somatomammotropin (hCS) molecule. Science, 173, 56-58.

LI C. H., DIXON J.S., GORDON D., KNORR J., 1972. Amino-acid sequence of sheep pituitary growth hormone. Int. J. Peptide Protein Res., 4, 151-153.

LIGGINS G. C., KENNEDY P. C., 1968. Effects of electrocoagulation of the foetal lamb hypophysis on growth and development. J. Endocr., 40, 371-381.

LINZER D. I. H., NATHANS D., 1984. Nucleotide sequence of a growth-related mRNA encoding a number of the prolactin-growth hormone family. Proc. nat. Acad. Sci. USA, 81, 4255-4259.

LOWE K. C., GLUCKMAN P. D., JANSEN C. A. M., NATHANIELSZ P. W., 1982. Changes in fetal and mat plasma ovine chorionic somatomammotropin concentrations in normal and premature parturition. J. Endocr., 94 (suppl.), abstract No. 36, p. 18. 
Mac MILLAN D. R., 1979. Secretion of polypeptide hormones by the placentomaternal unit and their effects on the fetus and newborn, 1-16. In NITZAN M., The influence of maternal hormones on the fetus and newborn. Karger, Basel.

MARTAL J., 1978a. Placental growth hormone in sheep : purification, properties and variations. Ann. Biol. anim. Bioch. Biophys., 18, 45-51.

MARTAL J., 1978b. Propriétés immunologiques de la somatomammotrophine chorionique ovine. C.R. Acad. Sci. Paris série D, 286, 245-248.

MARTAL J., 1980. L'hormone lactogène placentaire ovine. Purification et propriétés physicochimiques, immunologiques et biologiques. Etude de son rôle dans les mécanismes de contrôle de la gestation. Th. Doct. ès-Sci. Etat en Biologie, $499 \mathrm{p}$.

MARTAL J., 1981. L'hormone lactogène placentaire, 101-120. In CONSTANTIN A., MEISSONNIER E., L'utérus de la vache, Sté fse de Buiatrie, E.N.V.A., Maisons-Alfort, France.

MARTAL J., CHENE N., DE LA LLOSA P., 1985. Involvement of lysine residues in the binding of $\mathrm{hGH}$ and bGH to somatotropic receptors. FEBS Letters, 180, 295-299.

MARTAL J., DJIANE J., 1975. Purification of a lactogenic hormone in sheep placenta. Bioch. Biophys. Res. Comm., 65, 770-778.

MARTAL J., DJIANE J., 1976. Mammotrophic and growth promoting activities of a placental hormone in sheep. J. Steroid Bioch., 8, 415-417.

MARTAL J., DJIANE J., 1977. The production of chorionic somatomammotrophin in sheep. $J$. Reprod. Fert., 49, 285-289.

MARTAL J., DJIANE J., DUBOIS M. P., 1977. Immunofluorescent localization of ovine placental lactogen. Cell. Tiss. Res., 184, 427-433.

MARTAL J., LACROIX M. C., 1978. Production of chorionic somatomammotropin (oCS), fetal growth and growth of the placenta and the corpus luteum in ewes treated with 2-bromo- $\alpha$ ergocryptine. Endocrinology, 103, 193-199.

MARTIN J. M., GAGLIARDINO J. J., 1967. Effect of growth hormone on the isolated pancreatic islets of rat in vitro. Nature Lond., 213,630-631.

MCMILLEN I. E., JENKIN G., ROBINSON J. S., KINGSTON E. J., THORBURN G. D., 1977. Prolactin concentrations in foetal and neonatal sheep : effect of thyrotrophin releasing hormone, hypoxia and chlorpromazine. J. Endocr., 75, $54 \mathrm{p}$.

MILNER R. D. G., HILL D. J., 1984. Fetal growth control : the role of insulin and related peptides. Clin. Endocrinol., 21, 415-433.

NATHANIELSZ P.W., 1976. The fetal thyroid, 215-231. In BEARD R. W., NATHALIELSZ P.W., Fetal physiology and medicine: The basis of perinatology, W.B. Saunders, London.

N'GUEMA EMANE M., DELOUIS C., KELLY P. A., DJIANE J., 1986. Evolution of prolactin and placental lactogen receptors in ewes during pregnancy and lactation. Endocrinology, 118, 695-700.

NICOLL C. S., MAYER G. L., RUSSELL S. M., 1986. Structural features of prolactins and growth hormones that can be related to their biological properties. Endocr. Rev., 7, 169-203.

NIELSEN P. V., PEDERSEN H., KAMPMANN E. M., 1979. Absence of human placental lactogen in an otherwise uneventful pregnancy. Am. J. Obstet. Gynecol., 135, 322-326.

OBREGON M. J., MALLOL J., PASTOR R., MORREALE DE ESCOBAR G., ESCOBAR DE REY F., 1984. L-thyroxine and 3,5,3'-triodo-L-thyromine in rat embryos before onset of fetal function. Endocrinology, 114, 305-307.

PARKES M. J., HILL D. J., 1985. Lack of growth hormone-dependent somatomedins or growth retardation in hypophysectomized fetal lambs. J. Endocr., 104, 193-199.

RATTRAY P. V., GARRETT W. N., EAST N. E., HINMAN N., 1974. Growth development and composition of the ovine conceptus and mammary gland during pregnancy. J. anim. Sci., 38, 613-629.

RECHLER M. M., EISEN H. J., HIGA O. Z., NISSLEY S. P., MOSES A. C., SCHILLING E. E., FENOY I., BRUNI C. B., PHILIPPS L. S., BAIRD K. L., 1979. Characterization of a somatomedin (insulin-like growth factor) synthesized by fetal rat liver organ cultures. J. biol. Chem, 254, 7942-7950.

REDDY S., WATKINS W. B., 1978. Purification and some properties of ovine placental lactogen. $J$. Endocr., 78, 59-69. 
ROBINSON J. S., KINGSTON E. J., JONES C. T., THORBURN G. D., 1979. Studies on experimental growth retardation in sheep. The effect of removal of endometrial caruncles on fetal size and metabolism. J. dev. Physiol., 1, 379-398.

RUSSELL J., SHERWOOD L. M., KOWALSKI K., SCHNEIDER A. B., 1981. Recombinant hormones from fragments of human growth hormone and human placental lactogen. $J$. biol. Chem. 256, 296-300.

SADE S., 1987. Recherche d'une méthodologie pour l'étude du rôle physiologique de l'hormone placentaire lactogène (oPL) dans la croissance embryonnaire. Th. Doct. $3^{e}$ cycle, $41 \mathrm{p}$.

SCHIMPFF R. M., DONNADIEU M., GAUTHIER M., 1981. Somatomedin activity measured as sulphate factor in culture media from normal human liver and connective tissues explants. Effects of human growth hormone. Acta endocrinol., 98, 24-28.

SEN-MAJUMDAR A., MARTHY U., DAS M., 1986. A new-trophoblast-derived growth factor from human plancenta : purification and receptor identification. Biochemistry, 25, 627-634.

SERVELY J. L., N'GUEMA EMANE M., HOUDEBINE L. M., DJIANE J., DELOUIS C., KELLY P. A., 1983. Comparative measurement of the lactogenic activity of ovine placental lactogen in rabbit and ewe mammary gland. Gen. comp. Endocr., 51, 255-262.

SINGH R. N. P., SEAVEY B. K., RICE V. P., LINDSEY T. T., LEWIS U. I., 1974. Modified forms of human growth hormone with increased biological activities. Endocrinology, 94, 883-891.

SNYDER J. M., D'ERCOLE A. J., 1987. Somatomedin C/insulin-like growth factor I production by human fetal lung tissue maintained in vitro. Exp. Lung. Res., 13, 449-458.

STOKES H., BODA J. M., 1968. Immunofluorescent localization of growth hormone and prolactin in adenohypophysis of fetal sheep. Endocrinology, 83, 1362-1366.

SWENNE I., HILL D. J., STRAIN A. J., MILNER R. D. G., 1987. Effects of human placental lactogen and growth hormone on the production of insulin and somatomedin $\mathrm{C} /$ insulin-like growth factor I by human fetal pancreas in tissue culture. J. Endocr., 113, 297-303.

TAYLOR M. J., JENKIN G., ROBINSON J.S., THORBURN G. D., FRIESEN H., CHAN J.S. D., 1980. Concentrations of placental lactogen in chronically catheterised ewes and fetuses in late pregnancy. J. Endocr., 85, 27-34.

TAYLOR M. J., MCMILLEN I. C., JENKIN G., ROBINSON J.S., THORBURN G. D., 1983. The regulation of ovine placental lactogen the role of the fetal hypothalamic-pituitary axis. J. dev. Physiol., 5, $251-258$.

THORBURN G. D., 1974. The role of the thyroid gland and kidneys in fetal growth, 185-200. In Size at birth, Ciba Found. Symp. No. 27, Elsevier, Excerpta med., Amsterdam.

TSUSHIMA T., FRIESEN H. G., 1973. Radioreceptor assay for growth hormone. J. Clin. endocrinol. Metab., 37, 334-336.

VEZINHET A., KHERIF J. P., BOUTHIER E., 1974. Effet lipolytique in vivo de l'hormone somatotrope chez des agneaux normaux et hypophysectomisés soumis ou non à un jeûne. Ann. Biol. anim. Bioch. Biophys., 14, $781-791$.

VLIET G. van, STYNE D. M., KAPLAN S. L., GRUMBACH M. M., 1983. Hormone ontogeny in the ovine fetus. XVI plasma immunoreactive somatomedin C/insulin-like growth factor $\mathrm{I}$ in the fetal and neonatal lambs and in the pregnant ewe. Endocrinology, 113, 1716-1720.

WATERS M. J., ODDY V. H., MCCLOGHRY C. E., GLUCKMAN P. D., DUPLOCK R., OWENS P. C., BRINSMEAD M. W., 1985. An examination of the proposed roles of placental lactogen in the ewes by means of antibody neutralization. J. Endocr., 106, 377-386. 